\title{
Identifying New 'Hotspot' Heavy Metal Contamination in Industrial Zone Soil
}

\author{
Predrag Ilić ${ }^{1 *}$, Tatjana Nišić2 ${ }^{2}$ Svetlana Ilić1, Ljiljana Stojanović Bjelićc \\ ${ }^{1}$ PSRI Institute for Protection and Ecology of the Republic of Srpska, Banja Luka, Republic of Srpska, \\ Bosnia and Herzegovina \\ ${ }^{2}$ City of Banja Luka, Banja Luka, Republic of Srpska, Bosnia and Herzegovina \\ ${ }^{3}$ Apeiron Pan-European University, Banja Luka, Republic of Srpska, BiH, Republic of Srpska, \\ Bosnia and Hercegovina
}

Received: 6 August 2019

Accepted: 15 October 2019

\begin{abstract}
Concentrations of dangerous and harmful substances (PCB, TPH and heavy metals) were determined in soils in an industrial zone near the center of Banja Luka and the Vrbas River. PCB, TPH and heavy metals were found in the analysis location as a result of general anthropogenic factors. Contaminated soils have a negative impact on human health and the environment. The mean concentrations of $\mathrm{Pb}$, TPH, Cu, PCB, Ni, Cd and Hg were 4874, 4105, 545.7, 282.1, 225.7, 12.15 and $5.896 \mathrm{mg} / \mathrm{kg}$, respectively. Results show that concentrations were very high for all analyzed parameters, and these values indicated that the soil was highly polluted. Principal component analysis has shown that industrial factors and human activities are the cause of pollution. At the location it is necessary to determine the origin of pollution and recultivation and remediation activity of planned activity.
\end{abstract}

Keywords: hotspot, soils, heavy metals, TPH, PCB

\section{Introduction}

Identification and treatment of contaminated and unsafe locations (hotspots, hazard sites, blackspots, sites with promise, high-risk sites, and accident-prone sites) is the first major step in safety assessment $[1,2]$. The former industrial complex Incel Banja Luka Cellulose Factory is categorized as a hotspot (waste from cellulose and viscose factory) [3, 4], and decontamination of soil contaminated by polychlorinated biphenyl (PCB) oils from transformer stations in the vicinity of the factory

*e-mail: predrag.ilic@institutzei.net has been suggested. The location was recognized as a hotspot from the aspect of PCB. Previous research was based on analysis of PCBs and organochlorine pesticides in air $[5,6]$, because chlorine liquefaction units (KREBS SWISS Technology) were installed on the site in 1971-1980 for chlorine drying and cooling 67 tpd, chlorine compression 35 tpd and chlorine liquefaction 50 tpd [7]. Previous studies indicate that the level of PCBs on several sampling sites in Banja Luka was as high as $400.000 \mathrm{ng} / \mathrm{g}(400 \mathrm{mg} / \mathrm{kg})$ of the dry soil sample, which are two orders of magnitude higher than on any other investigated site performed by UMASA.RECETOX [8].

Analysis of total petroleum hydrocarbons (TPH) and heavy metals so far have not been performed in location. 
Inorganic pollutants (TPH, PCB and heavy metals $\mathrm{Cd}, \mathrm{Pb}, \mathrm{Ni}, \mathrm{Cu}$ and $\mathrm{Hg}$ ) can be strongly accumulated in soil, water and plants, and significant quantities of toxic metals are discharged into ecosystems [9]. TPH and $\mathrm{PCB}$ are ubiquitous class organic pollutants that are a human health risk [10]. Heavy metals (HMs) occur naturally in the environment; however, the concentration of some HMs has increased tremendously since the beginning of the industrial revolution due to many industrial activities [11]. Heavy metal pollution has attracted more attention because of its toxicity and mobility from polluted soil/water/air to living beings [12].

During the war of 1991-1995 a large number of industrial buildings were damaged, destroyed or devastated, including the Incel factory. Incel is a former company based in Banja Luka that originally manufactured cellulose, viscose and paper products. Established in 1954, it was a major industrial conglomerate in the field during the socialist era, employing up to 6,500 workers. Following a period of decline in the 1980s and the War in Bosnia and Herzegovina in the 1990s, the destroyed factory was subsequently split into several smaller enterprises. The result was the emission of various toxic substances into all components of the environment.

This research is focused on the presentation and discussion of the data related to contamination of soils by dangerous and harmful substances (PCB, TPH and heavy metals). The primary aim of this study was to determine soil pollution in the Incel industrial complex, Banja Luka, Republic of Srpska, Bosnia and Herzegovina, probable hotspot of heavy metals in Banja Luka, Republic of Srpska, Bosnia and Herzegovina.

\section{Material and Methods}

\section{Location}

The object of our research was to determine soil pollution at the Incel location (former cellulose factory, now industrial complex) $3 \mathrm{~km}$ from the center of Banja Luka - the second-largest city in Bosnia and Herzegovina with a population of 185,000 . The city is situated in a basin $164 \mathrm{~m}$ above sea level. The average annual temperature reaches $10.7^{\circ} \mathrm{C}$, the average January temperature is $0.8^{\circ} \mathrm{C}$, and the average temperature in July reaches $21.3^{\circ} \mathrm{C}$.

\section{Sampling and Analysis}

Samplings were performed in eight locations in the Incel industrial complex during April 2019. Sampling of the soil was carried out with Eijkelkamp agrisearch sampling equipment (Netherlands). Physical and chemical analyses were conducted on the samples' ph, organic matter, TPH, PCB (sum PCB 28, PCB 52, PCB 101, PCB 138, PCB 153 and PCB 180), and total forms of heavy metal pollution and existing pollution were monitored. Acidity $(\mathrm{pH})$ was measured in deionized water, organic matter content by applying Tyurin's method, and TPH and PCB analysis was performed by gas chromatography. Heavy metal concentrations were processed based on the principles described in Standard Methods with disintegration techniques and analyzed and according to national legislation [13].

\section{Statistical Analysis}

Statistical data processing while determining the relationship between TPH, PCB, and heavy metals was calculated with correlation analysis. A bivariate correlations study (Spearman's, Pearson's and Kendall rank correlation coefficient test) was performed, and a significance level of $\mathrm{p}$ value $<0.05, \mathrm{p}<0.01$ and $\mathrm{p}<0.001$ was used. Descriptive statistical operations like mean, median, standard deviation (SD), variance, minimum (min), maximum (max), skewness and Kurtosis test were applied for analysing the measured data. Statistical analyses (Spearman's, Pearson's and Kendall's correlation coefficient tests) and factor analysis (principal component analysis for pollutants) were applied for getting the qualitative information of the source of the five types of heavy metals, TPH and PCB. We used Excel 2016 JASP 0.8.5.1 software for statistical data processing.

\section{Results and Discussion}

In the research, pollutants, TPH and $\mathrm{PCB}$, and heavy metal concentrations $(\mathrm{Cd}, \mathrm{Pb}, \mathrm{Ni}, \mathrm{Cu}$ and $\mathrm{Hg}$ ) that originate from human activity were determined. In Table 1 all of the data were first processed for statistical analysis. As can be seen, $\mathrm{Pb}$ is the pollutant with the highest mean concentration (4874 mg/kg), followed by $\mathrm{TPH}, \mathrm{Cu}, \mathrm{PCB}, \mathrm{Ni}, \mathrm{Cd}$ and $\mathrm{Hg}$, with mean concentrations of 4105, 545.7, 282.1, 225.7, 12.15 and $5.896 \mathrm{mg} / \mathrm{kg}$, respectively.

Concentrations of PCB and heavy metals are greater than measured values during other surveys [14-19].

In small samples, skewness test values greater or less than 1.96 are sufficient to establish normality of the data (for $\mathrm{PCB}, \mathrm{Pb}, \mathrm{Ni}$ and $\mathrm{Hg}$ ) [20]. Skewness tests for $\mathrm{TPH}, \mathrm{Cd}$ and $\mathrm{Cu}$ show that data distribution is not normal, which is confirmed by the Kurtosis test. Coefficient of variation (CV) is an index showing the extent of variability in relation to the mean of the samples. It can be used for identifying the anthropogenic contribution degree for pollution in environmental studies. If $\mathrm{CV}<0.10$ and $>0.90$ are mean, low and high anthropogenic contributions, respectively [21]. Analyzing pollutants have $\mathrm{CV}>0.90$ (except $\mathrm{Hg}$ ). Values for $\mathrm{PCB}, \mathrm{Ni}, \mathrm{Pb}, \mathrm{Cu}, \mathrm{Cd}$ and $\mathrm{TPH}$, are 0.94, 1.03, 1.41, 1.57, 2.19 and 2.66, respectively. These values indicate high anthropogenic contribution, and concentrations of 
Table 1. Statistical summary of pollutants (TPH, PCB and heavy metals).

\begin{tabular}{|c|c|c|c|c|c|c|c|}
\hline & $\mathrm{TPH}$ & $\mathrm{PCB}$ & $\mathrm{Cd}$ & $\mathrm{Pb}$ & $\mathrm{Ni}$ & $\mathrm{Cu}$ & $\mathrm{Hg}$ \\
\hline Valid & 8 & 8 & 8 & 8 & 8 & 8 & 8 \\
\hline Min & 20 & 25 & 0.42 & 158 & 78.9 & 44.6 & 0.94 \\
\hline Max & 31090 & 600 & 77.3 & 18138 & 706 & 2488 & 11.6 \\
\hline Mean & 4105 & 282.1 & 12.15 & 4874 & 225.7 & 545.7 & 5.896 \\
\hline Median & 107.0 & 196.0 & 1.400 & 605.0 & 112.0 & 152.0 & 5.950 \\
\hline Std. Deviation & $1.091 \mathrm{e}+4$ & 264.3 & 26.55 & 6883 & 232.8 & 855.6 & 4.586 \\
\hline Coefficient of Variation & 2.66 & 0.94 & 2.19 & 1.41 & 1.03 & 1.57 & 0.78 \\
\hline Variance & $1.191 \mathrm{e}+8$ & $6.984 \mathrm{e}+4$ & 704.7 & $4.738 \mathrm{e}+7$ & $5.418 \mathrm{e}+4$ & $7.320 \mathrm{e}+5$ & 21.03 \\
\hline Skewness & 2.820 & 0.3879 & 2.739 & 1.332 & 1.726 & 2.129 & 0.1222 \\
\hline Kurtosis & 7.963 & -2.169 & 7.598 & 0.5662 & 1.895 & 4.395 & -2.044 \\
\hline
\end{tabular}

pollutants in the soil samples varied significantly from location to location.
The results correlation analysis are shown in Table 2. The results of the correlation analysis $\mathrm{Cd}$ and

Table 2. Correlation between pollutants (TPH, PCB and heavy metals).

\begin{tabular}{|c|c|c|c|c|c|c|}
\hline & \multicolumn{2}{|c|}{ Pearson } & \multicolumn{2}{|c|}{ Spearman } & \multicolumn{2}{|c|}{ Kendall } \\
\hline & $\mathrm{r}$ & $\mathrm{p}$ & rho & $\mathrm{p}$ & tau B & $\mathrm{p}$ \\
\hline TPH - PCB & 0.510 & 0.197 & $0.877 * *$ & 0.004 & $0.784 * *$ & 0.010 \\
\hline $\mathrm{TPH}-\mathrm{Cd}$ & -0.111 & 0.793 & 0.184 & 0.663 & 0.231 & 0.442 \\
\hline $\mathrm{TPH}-\mathrm{Pb}$ & -0.253 & 0.545 & 0.024 & 0.954 & 0.038 & 0.899 \\
\hline TPH - Ni & -0.204 & 0.628 & -0.220 & 0.601 & -0.113 & 0.702 \\
\hline $\mathrm{TPH}-\mathrm{Cu}$ & 0.243 & 0.561 & 0.268 & 0.520 & 0.189 & 0.524 \\
\hline $\mathrm{TPH}-\mathrm{Hg}$ & 0.159 & 0.707 & -0.220 & 0.601 & -0.189 & 0.524 \\
\hline $\mathrm{PCB}-\mathrm{Cd}$ & -0.035 & 0.934 & 0.576 & 0.135 & 0.415 & 0.164 \\
\hline $\mathrm{PCB}-\mathrm{Pb}$ & -0.021 & 0.961 & 0.374 & 0.362 & 0.222 & 0.451 \\
\hline PCB - Ni & -0.214 & 0.610 & 0.096 & 0.820 & 0.074 & 0.802 \\
\hline $\mathrm{PCB}-\mathrm{Cu}$ & 0.167 & 0.693 & 0.602 & 0.114 & 0.371 & 0.209 \\
\hline PCB $-\mathrm{Hg}$ & 0.090 & 0.833 & -0.096 & 0.820 & -0.074 & 0.802 \\
\hline $\mathrm{Cd}-\mathrm{Pb}$ & $0.832 *$ & 0.010 & $0.766 *$ & 0.027 & $0.618 *$ & 0.034 \\
\hline $\mathrm{Cd}-\mathrm{Ni}$ & 0.524 & 0.183 & 0.587 & 0.126 & 0.473 & 0.105 \\
\hline $\mathrm{Cd}-\mathrm{Cu}$ & $0.936 * * *$ & $<.001$ & $0.946 * * *$ & $<.001$ & $0.837 * *$ & 0.004 \\
\hline $\mathrm{Cd}-\mathrm{Hg}$ & 0.499 & 0.208 & 0.419 & 0.301 & 0.255 & 0.383 \\
\hline $\mathrm{Pb}-\mathrm{Ni}$ & $0.819 *$ & 0.013 & 0.714 & 0.058 & 0.571 & 0.061 \\
\hline $\mathrm{Pb}-\mathrm{Cu}$ & $0.719 *$ & 0.044 & 0.810 * & 0.022 & $0.643 *$ & 0.031 \\
\hline $\mathrm{Pb}-\mathrm{Hg}$ & 0.435 & 0.281 & 0.405 & 0.327 & 0.357 & 0.275 \\
\hline $\mathrm{Ni}-\mathrm{Cu}$ & 0.415 & 0.306 & 0.500 & 0.216 & 0.357 & 0.275 \\
\hline $\mathrm{Ni}-\mathrm{Hg}$ & 0.093 & 0.827 & -0.048 & 0.935 & -0.071 & 0.905 \\
\hline $\mathrm{Cu}-\mathrm{Hg}$ & 0.563 & 0.146 & 0.571 & 0.151 & 0.429 & 0.179 \\
\hline
\end{tabular}

$* \mathrm{p}<.05, * * \mathrm{p}<.01, * * * \mathrm{p}<.001$ 
1

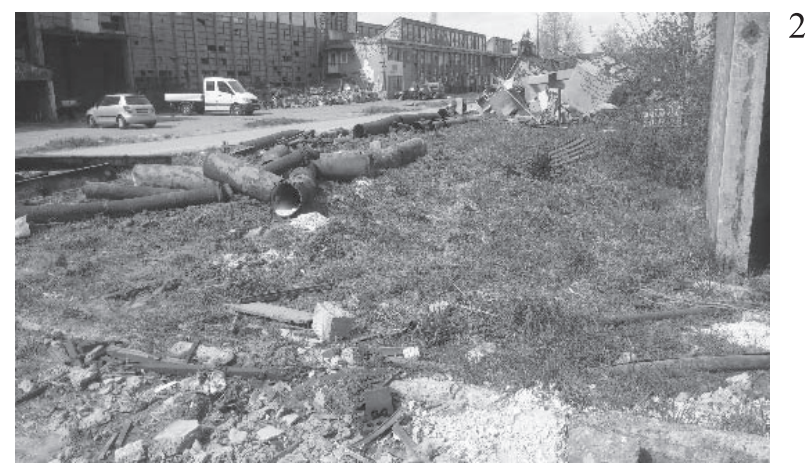

3

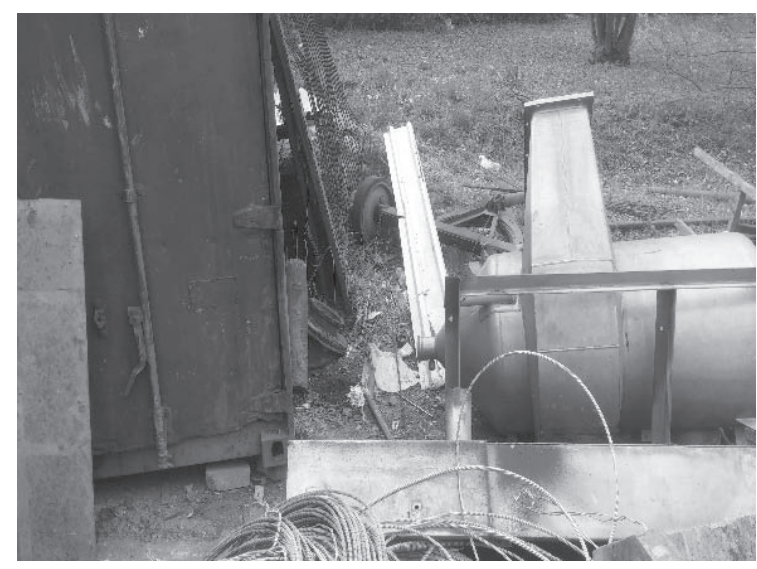

5

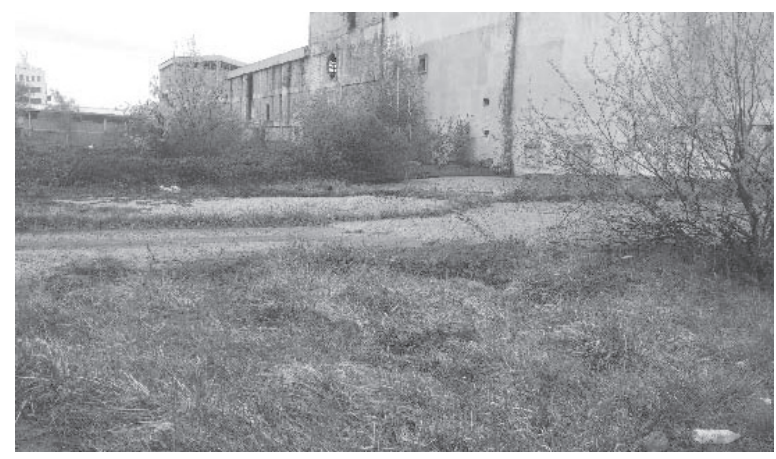

7

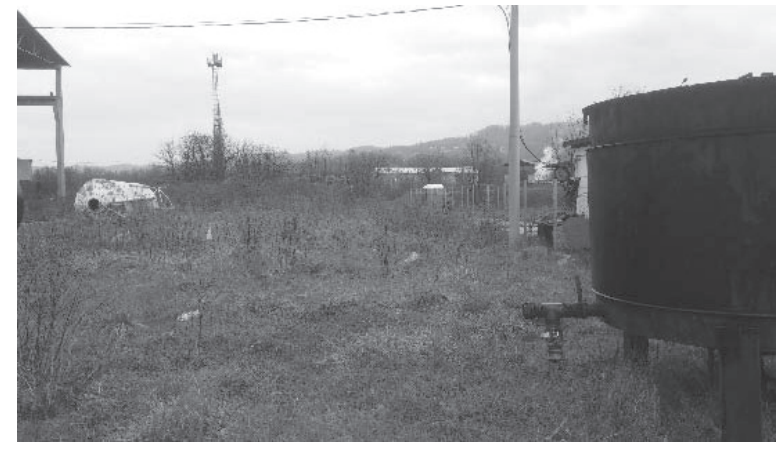

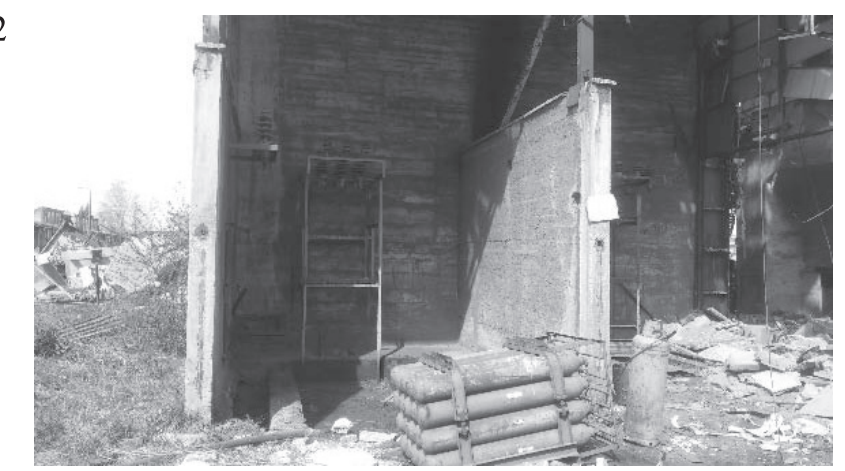

4

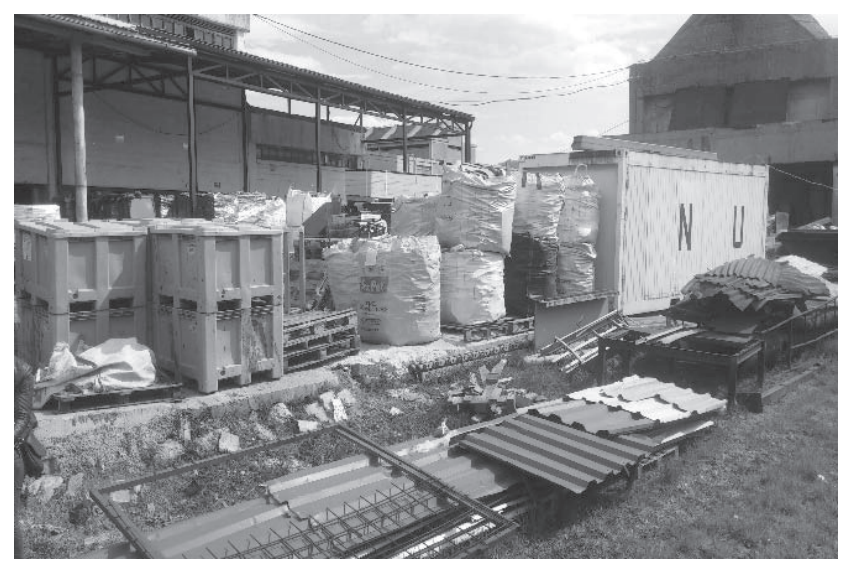

6

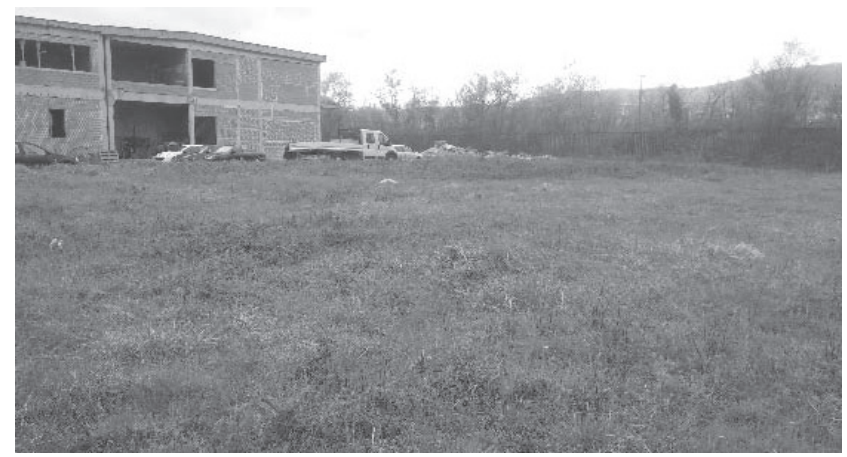

8

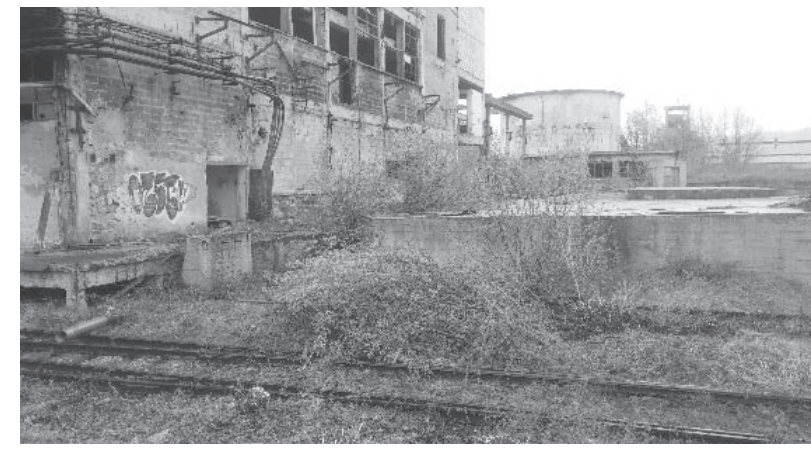

Fig. 1. Sampling locations (1-8).

$\mathrm{Cu}$ is positive for the level of significance $\mathrm{p}<0.001$ (Pearson's and Spearman's Correlation Coefficient test). Correlation TPH and PCB are shown for the level of significance $\mathrm{p}<0.01$ (Spearman's Correlation Coefficient test). The results for $\mathrm{Cd}$ and $\mathrm{Pb}$ and $\mathrm{Pb}$ and $\mathrm{Cu}$ are shown for the level of significance $\mathrm{p}<0.05$ (Spearman's, Pearson's and Kendall's correlation coefficient tests).
Correlation $\mathrm{Cd}$ and $\mathrm{Cu}$ and correlation $\mathrm{Cd}$ and $\mathrm{Pb}$ and correlation $\mathrm{Pb}$ and $\mathrm{Ni}$ are a strong positive, which means that high $\mathrm{Cd} / \mathrm{Pb}$ variable scores go with high $\mathrm{Cu} / \mathrm{Pb} / \mathrm{Ni}$ variable scores (and vice versa). Correlation $\mathrm{TPH}$ and $\mathrm{PCB}$, correlation $\mathrm{Pb}$ and $\mathrm{Cu}$ and correlation $\mathrm{Cu}$ and $\mathrm{Hg}$ are moderately positive, which means there is a tendency for high $\mathrm{TPH} / \mathrm{Pb} / \mathrm{Cu}$ variable scores to 
Table 3. Component loading for pollutants (TPH, PCB and heavy metals), according to factor analysis.

\begin{tabular}{|c|c|c|c|c|}
\hline & RC 1 & RC 2 & RC 3 & Uniqueness \\
\hline $\mathrm{Cd}$ & 0.614 & 0.492 & $\cdot$ & 0.101 \\
\hline $\mathrm{Cu}$ & 0.507 & 0.541 & $\cdot$ & 0.089 \\
\hline $\mathrm{Hg}$ & $\cdot$ & 1.025 & $\cdot$ & 0.150 \\
\hline $\mathrm{Ni}$ & 1.032 & $\cdot$ & $\cdot$ & 0.133 \\
\hline $\mathrm{PCB}$ & $\cdot$ &. & 0.916 & 0.224 \\
\hline $\mathrm{Pb}$ & 0.897 & $\cdot$ & $\cdot$ & 0.049 \\
\hline $\mathrm{TPH}$ & $\cdot$ &. & 0.817 & 0.241 \\
\hline
\end{tabular}

go with high $\mathrm{PCB} / \mathrm{Cu} / \mathrm{Hg}$ variable scores (and vice versa). Variables are not normally distributed, and more important is the Spearman rank correlation method. By normal standards, according to Spearman's correlation, the association between the two variables $(\mathrm{Cd}$ and $\mathrm{Cu}$; $\mathrm{Cd}$ and $\mathrm{Pb} ; \mathrm{Pb}$ and $\mathrm{Ni}$; $\mathrm{TPH}$ and $\mathrm{PCB} ; \mathrm{Pb}$ and $\mathrm{Cu}$ and $\mathrm{Cu}$ and $\mathrm{Hg}$ ) would be considered statistically significant. Such results suggest that these pollutant pairs might have similar sources or have been affected by similar factors. Values of correlation analysis for other pollutants is not relevant.

The research was applied factor analysis (FA), whose results determine the effective variable factors. The aim FA is to create fewer factors by combining two or more variables. These fields may easily hypothesize too many variables, so factor analysis helps to find essentials of a theory [22]. Principal component analysis (PCA) was used. The primary output for PCA shows the correlation between each variable of a principal component and the variable factors (RC1, RC2 and RC3) (Table 3).

PCA, which attempts to explain the variance of a large dataset of intercorrelated variables with a smaller set of independent variables, is a powerful pattern recognition tool [9]. PCA's approach to data reduction is to create one or more index variables (components) from a set of measured variables. Fig. 2a) shows what PCA is doing to combine seven measured variables into three components: $\mathrm{RC} 1, \mathrm{RC} 2$ and $\mathrm{RC} 3$. The direction of the arrows shows how the variables (TPH, PCB, Cd, $\mathrm{Pb}, \mathrm{Ni}, \mathrm{Cu}$ and $\mathrm{Hg}$ ) contribute to the variable factors. The weights to emphasize $\mathrm{Ni}$ and $\mathrm{Pb}$ (for $\mathrm{RC} 1$ ), $\mathrm{Hg}$ (for $\mathrm{RC} 2$ ) and TPH and PCB (for RC3) variables more than others. Using PCA we obtained three factors that clarify the grouping of pollutants: factor $\mathrm{RC} 1$ represents the heavy metals $\mathrm{Ni}, \mathrm{Pb}, \mathrm{Cd}$ and $\mathrm{Cu}$; factor $\mathrm{RC} 2$ represents the heavy metals $\mathrm{Hg}, \mathrm{Cu}$ and $\mathrm{Cd}$; and $\mathrm{RC} 3$ represents $\mathrm{PCB}$ and TPH.

The RC1 factor is an industrial factor in location $(\mathrm{Ni}, \mathrm{Pb}, \mathrm{Cd}$ and $\mathrm{Cu}$ ) and explained $48.94 \%$ of total variance. $\mathrm{Pb}$ and $\mathrm{Ni}$ were strong positively loaded $(>0.75)$. $\mathrm{Cd}$ and $\mathrm{Cu}$ were moderately loaded $(0.75-0.50)$ [23] (Table 4). Ni, which occurs naturally in the Earth's crust, may enter the environment as a
Table 4. Eigenvalue and percentage variance for factors.

\begin{tabular}{|c|c|c|}
\hline RC & Eigenvalue & \% variance \\
\hline 1 & 3.42582 & 48.94 \\
\hline 2 & 1.78048 & 25.435 \\
\hline 3 & 0.805846 & 11.512 \\
\hline 4 & 0.53209 & 7.6013 \\
\hline 5 & 0.431051 & 6.1579 \\
\hline 6 & 0.0247031 & 0.3529 \\
\hline
\end{tabular}

result of natural processes and mostly by human activities [13]. Other heavy metals are from industrial activities.

The RC2 factor is in relation with the accumulator recycling factory in location and explained $25.435 \%$ of total variance. $\mathrm{Hg}$ was strong positively loaded $(>0.75)$. $\mathrm{Cu}$ was moderately loaded $(0.75-0.50)$ and $\mathrm{Cd}$ was weakly loaded (0.50-0.30) (Table 4$). \mathrm{Hg}$ is not essential at low levels for all living organisms.

The RC3 factor is exclusively related to waste from transformers in location. The source of PCB and

a)

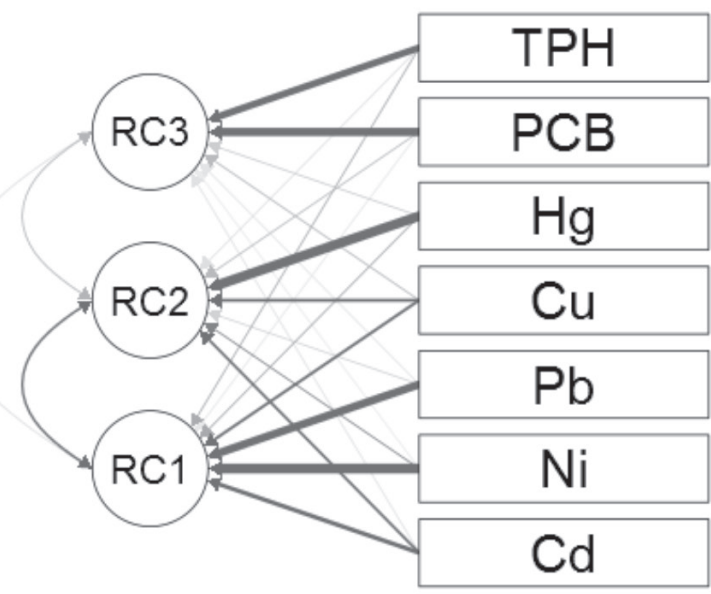

b)

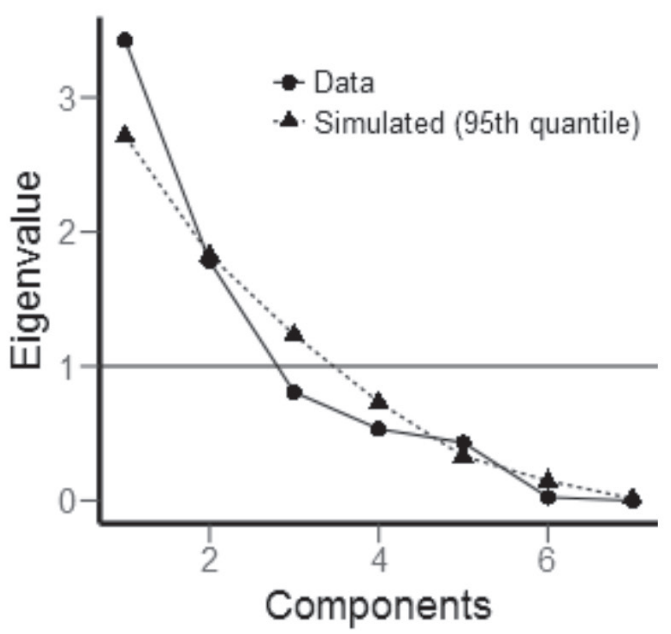

Fig. 2. Path diagram a) and scree plot b). 
Table 5. Degree of soil load.

\begin{tabular}{|c|c|c|c|c|c|c|c|c|}
\hline \multirow{2}{*}{ Location } & \multirow{2}{*}{ Type of soil } & \multirow{2}{*}{$\mathrm{pH}\left(\mathrm{H}_{2} \mathrm{O}\right)$} & \multirow{2}{*}{$\begin{array}{c}\text { Organic matter } \\
(\%)\end{array}$} & \multicolumn{5}{|c|}{ Degree of soil load (\%) } \\
\hline & & & & Cd & $\mathbf{P b}$ & $\mathbf{N i}$ & $\mathrm{Cu}$ & Hg \\
\hline 1. & Clay & 4.8 & 3.0 & 537 & 775 & 230 & 897 & 526 \\
\hline 2. & Clay & 6.9 & 3.2 & 94 & 278 & 145 & 123 & 63 \\
\hline 3. & Clay & 6.6 & 2.8 & 510 & 8112 & 941 & 348 & 401 \\
\hline 4. & Clay & 6.7 & 3.3 & 3865 & 12092 & 627 & 2073 & 535 \\
\hline 5. & Clay & 7.9 & 6.8 & 46 & 4400 & 129 & 130 & 581 \\
\hline 6. & Clay & 7.4 & 4.7 & 21 & 199 & 136 & 37 & 10 \\
\hline 7. & Clay & 7.3 & 3.6 & 21 & 290 & 170 & 45 & 100 \\
\hline 8. & Clay & 7.5 & 3.1 & 33 & 105 & 105 & 70 & 767 \\
\hline \multicolumn{4}{|c|}{ Average values: } & 641 & 3281 & 310 & 465 & 373 \\
\hline
\end{tabular}

TPF pollution is related to damaged and destroyed transformers and barrels at the Incel factory in the waste storage area. This factor explained $11.512 \%$ of total variance (Table 4).

Fig. 2b) shows the PCA scree plot. Eigen values higher than one were taken as criterion for evaluating the principal components required to explain the sources of variance in the data. According to rotated oblique percentage variance, three factors explained $85.89 \%$ of the total variance.

The degree of soil load is calculated according to the Rulebook [18] (Table 5). Average values degree of soil load show that $\mathrm{V}$ class is a land of very high load, with degree of soil more than 200\%. Locations 3 and 4 are very load, especially lead. Ecological investigation levels and health investigation levels (commercial/ industrial includes premises such as shops and offices as well as factories and industrial sites) [24] are exceeded for all tested parameters.

\section{Conclusions}

Results indicate that the soils in the research area suffer different levels of dangerous and harmful substances (PAH, TPH and heavy metals), and the pollution status of the different pollutants varies among sampling locations. Results show that concentrations were very high for all analyzed parameters. These values indicate that the soil was highly polluted. Principal component analysis shows that they are industrial factors and human activities caused the pollution.

The higher content of TPH, PCB and heavy metals suggest that it is necessary to provide additional investigation other than heavy metals and a larger number of samples on location. In regards to these results, it is possible to estimate their influence in the examined area. Since several sites are close to the aquatic environment, sediment and biota samples should be analyzed as well. It is necessary to determine the origin of pollution, to perform the analysis of plant material and on the basis of the obtained results. Risk should be evaluated and recultivation and remediation activity planned.

\section{Acknowledgements}

The present study was conducted using equipment from the PSRI institute for protection and ecology of the Republic of Srpska, Banja Luka. This research was done in the frame of the project "Environmental assessment correlated with environmental risks in an urban area" granted by the Ministry for Scientific and Technological Development, Higher Education and Information Society of Republic of Srpska (19/6020/961-96/18).

\section{Conflict of Interest}

The authors declare no conflict of interest.

\section{References}

1. BANDYOPADHYAYA R., MITRA S. Comparative Analysis of Hotspot Identification Methods in the Presence of Limited Information. In $3^{\text {rd }}$ International Conference on Road Safety and Simulation Transportation Research Board, Indianapolis, USA. 2011.

2. FERREIRA S., COUTO A. Hot-Spot Identification: Categorical Binary Model Approach. Transportation research record. 2386 (1), 1, 2013.

3. JICA expert team (NIPPON KOEI CO., LTD.). The project for master plan for remediation of hotspots in Bosnia and Herzegovina. May 2014 Japan international cooperation agency. Ministry of foreign trade and economic relations, Bosnia and Herzegovina and Federal ministry of environment and tourism, Federation of Bosnia and Herzegovina. 2014. 
4. National implementation plan for the Stockholm convention in Bosnia and Herzegovina. Global Environment Facility United Nations Industrial Development Organization. Bosnia and Herzegovina Ministry of foreign trade and economic relations. 2015.

5. GASIC B., MACLEOD M., KLANOVA J., SCHERINGER M., ILIC P., LAMMEL G., PAJOVIC A., BREIVIK K., HOLOUBEK I., HUNGERBÜHLER K. Quantification of sources of PCBs to the atmosphere in urban areas: A comparison of cities in North America, Western Europe and former Yugoslavia. Environmental Pollution. 158 (10), 3230, 2010.

6. LAMMEL G., KLÁNOVÁ J., ERIĆ L., ILIĆ P., KOHOUTEK J., KOVACIĆ, I. Sources of organochlorine pesticides in air in an urban Mediterranean environment: volatilisation from soil. Journal of Environmental Monitoring. 13 (12), 3358, 2011.

7. KREBS SWISS Technology Chlorine Liquefaction Units, Reference List. [Internet]. 2019. Available from: http:// krebs-swiss.com/refclpro.pdf. (accessed on 30/04/2019).

8. Scientific report. [Internet]. 2019. Available from: http:// www.recetox.muni.cz/projekty/apopsbal/sources/final/ scientific-report.pdf. (accessed on 30/04/2019).

9. ÇIÇEK A., KÖSE E., TOKATLI C. Using Factor Analysis to Evaluate Sediment Quality of a Significant Mining Area in Turkey. Polish Journal of Environmental Studies. 28 (3), 2021, 2019.

10. MATTES T.E., EWALD J.M., LIANG Y., MARTINEZ A., AWAD A., RICHARDS P., HORNBUCKLE K., SCHNOOR J.L. PCB dechlorination hotspots and reductive dehalogenase genes in sediments from a contaminated wastewater lagoon. Environmental Science and Pollution Research. 25 (17), 16376, 2018.

11. JOHNBULL O., ABBASSI B., ZYTNER R. G. Risk assessment of heavy metals in soil based on the geographic information system-Kriging technique in Anka, Nigeria. Environmental Engineering Research. 24 (1), 150, 2018.

12. LINHUA S., SONGBAO F. Heavy Metals in the Surface Soil around a Coalmine: Pollution Assessment and Source Identification. Polish Journal of Environmental Studies. 28 (4), 2717, 2019.

13. RULEBOOK on allowable quantities of dangerous and hazardous matters in soil and irrigation water and methods for their testing ("Official Gazette of the Republic of Srpska", No. 56/16), 2016 [In Serbian].

14. CUI S., HOUGH R., FU Q., QI X., LIU D., COOPER P., LI, P., ZHANG, Z. Concentrations and uptake pathways of polychlorinated biphenyls from soil to grass. Ecotoxicology and environmental safety. 182, 109428, 2019.

15. CHAKRABORTY P., ZHANG G., LI J., SELVARAJ S., BREIVIK K., JONES K.C. Soil concentrations, occurrence, sources and estimation of air-soil exchange of polychlorinated biphenyls in Indian cities. Science of the total environment. 562, 928, 2016.

16. LI P., LIN C., CHENG H., DUAN X., LEI K. Contamination and health risks of soil heavy metals around a lead/zinc smelter in southwestern China. Ecotoxicology and Environmental Safety. 113, 391, 2015.

17. VANE C.H., KIM A.W., BERIRO D.J., CAVE M.R., KNIGHTS K., MOSS-HAYES V., NATHANAIL P.C. Polycyclic aromatic hydrocarbons (PAH) and polychlorinated biphenyls $(\mathrm{PCB})$ in urban soils of Greater London, UK. Applied Geochemistry. 51, 303, 2014.

18. OGBEH G.O., TSOKAR T.O., SALIFU E. Optimization of nutrients requirements for bioremediation of spentengine oil contaminated soils. Environmental Engineering Research. 24 (3), 484, 2018.

19. KIM A.W., VANE C.H., MOSS-HAYES V.L., BERIRO D.J., NATHANAIL C.P., FORDYCE F.M., EVERETT P.A. Polycyclic aromatic hydrocarbons (PAHs) and polychlorinated biphenyls (PCBs) in urban soils of Glasgow, UK. Earth and Environmental Science Transactions of the Royal Society of Edinburgh. 108 (2-3), 231, 2019.

20. GHASEMI A., ZAHEDIASL S. Normality tests for statistical analysis: a guide for non-statisticians. International journal of endocrinology and metabolism. 10 (2), 486, 2012.

21. CEPA (Chinese Environmental Protection Administration). Elemental background values of soils in China. Environmental Science Press of China, Beijing, 1990.

22. JASP Manual Seton Hall University Department of Psychology. [Internet]. 2018. Available from: https:// www.shu.edu/psychology/upload/JASP-Manual_SHURD-A_9-1-18.pdf. (accessed on 30/04/2019).

23. LIU C.W., LIN K.H., KUO Y.M. Application of factor analysis in the assessment of groundwater quality in a Blackfoot disease area in Taiwan. Science of the Total Environment. 313 (1-3), 77, 2003.

24. Assessment levels for Soil, Sediment and Water, Contaminated Sites Management Series, Version 4, revision 1. Department of Environment and Conservation (DEC), 2010. 